\title{
Nutritional Evaluation of Soybean Hulls with or without $\beta$-Mannanase Supplement on Performance, Intestinal Morphometric and Carcass Yield of Broilers Chickens
}

-Author(s)
Scapini LB"
Rorig A"
Ferrarini A"
Fülber LM"
Canavese M"
Silva AM"
Fernandes JIM" (D) https://orcid.org/0000-0001-8722-7424

Laboratório de Experimentação Avícola UFPR Department of Animal Science, Rua Pioneiro, $n^{\circ}$ 2153 Palotina Paraná 85.950-000 - Brazil.

Universidade Federal do Parana Ringgold standard institution - Zootecnia, Rua Pioneiro, 2153, Palotina, PR 85950-000 Brazil.

\section{-Mail Address}

Corresponding author e-mail address Jovanir Inês Muller Fernandes

Laboratório de Experimentação Avícola UFPR - Department of Animal Science, Rua Pioneiro, n²153 Palotina Paraná 85.950000 - Brazil.

Phone: +88 031659224

Email: ajpferr@usp.br

\section{- Keywords}

Soybean meal, Intestinal mucosa, Enzyme, Non-starch polysaccharides.

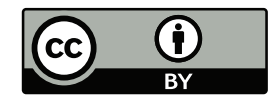

Submitted: 05/July/2017

Approved: 26/March/2018

\begin{abstract}
The objective was to evaluate the performance, intestinal morphology and carcass yield of broilers fed corn-soybean meal (SBM) diet or cornSBM-soybean hull (SH) with or without $\beta$-mannanase supplementation. Thousand four hundred and forty Cobb Slow-male- chicks were housed design following a factorial scheme $2 \times 2$ (corn-SBM diet and corn-SBM$\mathrm{SH}$ diet vs with and without $\beta$-mannanase), composing 4 treatments and 9 replicates each treatment, with 40 birds each replicate. At 21 days, corn-SBM diet supplemented with $\beta$-mannanase resulted in better $(p<0.05)$ feed conversion. At 42 days, the weight gain $(p<0.05)$ and feed intake $(p<0.05)$ of the birds fed diets containing SH was $2.6 \%$ and $2.9 \%$ higher than that of birds fed corn-SBM diets, respectively, independent of $\beta$-mannanase supplementation. Birds supplemented with $\beta$-mannanase had a lower length of villi $(p<0.05)$ and absorption area $(p<0.05)$ of jejunum mucosa, and higher $(p<0.05)$ relative liver weight. Diets with $\mathrm{SH}$ and without addition of $\beta$-mannanase resulted in higher relative liver weight $(p<0.05)$ and lower percentage of fat in the carcass. It was not found statistical differences $(p>0.05)$ in the quality of the poultry litter with the inclusion of the enzyme in the diet. The use of $\beta$-mannanase in diets with higher concentration of fiber improves the feed conversion of broilers from 1 to 21 days and can be an important nutritional and economic strategy in situations of unavailability of raw material of better quality. Corn-SBM-SH diet resulted in greater weight gain at 42 days than corn-SBM diet.
\end{abstract}

\section{INTRODUCTION}

Corn and soybean meal (SBM) are the two main ingredients of poultry and pig diets. Their utilization use by the animal directly affects growth performance, as they are the main sources of energy and protein diets. However, due to the price volatility of these ingredients, the poultry industry has increasing included locally available feedstuffs, which are usually rich in dietary fiber, to reduce production costs.

Dietary fiber (DF) has been considered a diluent in the diets of chickens, with negative effects on the voluntary energy intake and dietary nutrient digestibility (Jiménez-Moreno et al., 2016). Consequently, commercial diets, particularly fed to young broilers, are formulated to contain less than $3 \%$ fiber crude.

Dietary fiber is a major component of the plant cell wall and consists of both non-starch polysaccharides (NSP) and non-carbohydrate components (Bach Knudsen, 2001). The variable physiochemical properties of the polymers present in DF can modify dietary ion exchange capacity, viscosity, bulk, and fermentation in the gastrointestinal tract (GIT). In addition, DTmay encapsulate dietary nutrients, and interfere with digestion and absorption (Back Knudsen, 2014). This is especially true for soluble fibers, which have high water retention capacity, 
Scapini LB, Rorig A, Ferrarini A, Fülber LM, Canavese M, Silva AM, Fernandes JIM
Nutritional Evaluation of Soybean Hulls with or without $\beta$-Mannanase Supplement on Performance, Intestinal Morphometric and Carcass Yield of Broilers Chickens increasing digesta viscosity (Choct \& Annison, 1992). This increase in intestinal chyme viscosity reduces feed passage rate through the digestive tract, hinders the dispersion and the action of endogenous enzymes, and impairs nutrient diffusion or transport by the enterocytes (Choct et al., 2004). On the other hand, insoluble fiber cause increases the bulk of the digesta, eventually slowing digesta passage, which has been reported to improve dietary nutrient digestibility (Rogel et al., 1987). Recent research has demonstrated that the inclusion of moderate amounts of different fiber sources in broiler diets improves digestive organ development and increases the secretion of $\mathrm{HCl}$, bile acids, and enzymes (Mateos et al., 2012). These effects are associated with increased gastrointestinal reflux to the gizzard, increasing the contact between nutrients and digestive enzymes (González-Alvarado et al., 2007, Mateos et al., 2012). These changes may improve nutrient digestibility growth performance, gastrointestinal tract health, and eventually, animal welfare. Fiber in broiler diets is also reported to influence the behavior of birds, reducing cannibalism as birds spend more time eating than pecking each other (Hughes \& Duncan, 1972).

Depending on DF amount and type, as well as on the composition of the basal diet, the profile of the existing microbiota in the distal part of the GIT may also be affected. Dietary fiber is preferentially utilized by Lactobacillus and Bifidobacteria species, leading to the production of lactic acid and short-chain fatty acids (Nicholson et al., 2012). This results in low pH, which maintains the normal microorganism population, thus preventing the establishment of Salmonella and other pathogens in the GIT (Kamada et al., 2013).

Soybean hull (SH) is a by-product of soybean processing for oil and SBM production. Soybean hullscontainaround $75 \%$ of non-starch polysaccharides (NSP), out of which $60 \%$ are insoluble (Lo, 1989). Among the NSP present in soybeans are the $\beta$-mannans, which are polysaccharides with repeating units of mannose and galactose or glucose, or both (Jackson et al., 1999). Most mannans in SBM are present in its non-starch polysaccharide fraction (Dierick, 1989). According to Hsiao et al. (2006), the percentage of $\beta$-mannans present in non-dehulled SBM is between 1.33 and $2.14 \%$ and SBM dehulled between 1.02 and $1.51 \%$.

Mannans are also components of the surface of various fungi, bacteria and viruses, which provides them with the ability to stimulate the innate immune system of birds. This increases the energy expenditure for the immune system due to an increase in immune cell proliferation, such as monocytes and macrophages (Hsiao et al., 2006, Jackson, 2010).

The addition of exogenous enzymes to broiler diets containing moderate DF levels may be used as a strategy to increase the utilization of mannan-rich feedstuffs. The exogenous enzyme $\beta$-mannanase breaks down dietary $\beta$-mannans, in particular, chains of mannans, glucomannans and galactomannans (Jackson et al., 2004). The beneficial effect of the enzymatic degradation of $\beta$-mannan by addition of $\beta$-mannanase to diets containing SBM has been documented in broilers (Lee et al., 2003, Jackson et al., 2004, Kong et al., 2011).

The possibility of dietary $\beta$-mannan breakdown, and consequently, the release of substrates in the GIT may promote higher utilization of nutrients by specific groups of microorganisms, favoring their replication.

There is a growing interest in the inclusion of DF in poultry diets due to its possible effects on gut health, welfare and environment. Moreover, during the last decade, there has been dramatic shift in the landscape of the feed industry, in terms of feedstuff price and availability. There is increased availability of different alternative feed ingredients and coproducts. However, it is important to understand the implication of the use of these relatively new and potential DF sources in diets. The dietary inclusion of soybean hulls and other DF sources may be beneficial to the poultry industry as it may allow the reduction of feed costs, provided broiler performance is not compromised.

The objective of this study was to evaluate the performance, intestinal morphology and carcass yield of broilers fed corn-SBM or corn-SBM-soybean hull diets supplemented or not with $\beta$-mannanase.

\section{MATERIAL AND METHODS}

The experiment was conducted at the Experimental Poultry Department of the Federal University of Paraná, Palotina, state of Paraná, Brazil. All procedures of animal use and biological material collection were approved by the Ethics Committee of Animal Use in Experimentation, under the protocol number 01/2014.

\section{Birds and Experimental Diets}

In the experiment, 1440 one-d-old male Cobb Slow broilers were evaluated.

A completely randomized design in a $2 \times 2$ factorial arrangement (corn-SBM or corn-SBM-SH diets supplemented or not $\beta$-mannanase), consisting of four treatments with nine replicates (pens) of 40 birds each. 
Scapini LB, Rorig A, Ferrarini A, Fülber LM, Canavese M, Silva AM, Fernandes JIM
Nutritional Evaluation of Soybean Hulls with or without $\beta$-Mannanase Supplement on Performance, Intestinal Morphometric and Carcass Yield of Broilers Chickens
Soybean hull (33.5\% crude fiber) is a co-product of standard milling operations in the production of dehulled soybean meal and was added at $5 \%$ to the corn-SBM-SH diet. The corn-SBM and corn-SBM-SH diets contained $3.0 \%$ and $4.5 \%$ of crude fiber (CF), and were evaluated as low crude fiber and high crude fiber diets, respectively.

The $\beta$-mannanase enzyme used was a Beta-Dmannanase (Hemicell ${ }^{\circledR}$, EC 3.2.1.78, mannan endo1, 4- $\beta$-mannosidase; Elanco Companion Animal Health, Greenfield, IN, USA). It is an endohydrolyase, which degrades $\beta$-mannans and it is a fermentation product of Bacillus lentus. This enzyme cleaves randomly within the $1,4-\beta$-D-mannan main chain of galactomannan, galactogluco-mannan, and mannan (McCleary, 1988). The enzyme was included at a dosage of $400 \mathrm{~g} /$ ton.

The feeding program consisted of a starter (day 1 to day 21 post-hatch) and a grower (day 22 to day 42 post-hatch) diet. All diets were fed as mash. The ingredients and calculated chemical composition of the experimental diets are shown in Table 1.

Birds were housed in floor pens ( $\left.11.4 \mathrm{birds} / \mathrm{m}^{2}\right)$ with fresh wood shavings in an environmentally-controlled broiler house. The thermal comfort temperature was maintained according to age. Each pen was equipped with a feeder and nipple drinkers.

\section{Live Performance, Organ Collection and Intestinal Analyses}

Weekly, broilers and feed were properly weighed for the calculation of weight gain, feed intake, and feed conversion ratio per replicate until 42 days of age. Mortality was recorded on a daily basis.

At 21 and 42 days of each, nine birds per treatment were randomly selected, submitted to electrical stunning, and then slaughtered by severing the jugular vein. The bursa, intestines, pancreas, and liver were immediately removed, carefully stripped from adhering connective tissue and individually weighed. Relative organ weights were calculated as percentage of body weight.

The small intestine was removed, and fragments of approximately $5 \mathrm{~cm}$ length of the duodenum (from the pylorus to the distal portion of the duodenal loop), jejunum (from the distal portion of the duodenal loop to the Meckel's diverticulum) and ileum (from the ileocecum-colic valve) were cut, longitudinally opened, pinned on polystyrene plates, and washed with saline solution. Samples were fixed in buffered formalin, and embedded in paraffin. Each fragment was then cut
Table 1 - Ingredients and calculated chemical composition of experimental starter (1-21 days) and a grower (22-42 days) diets.

\begin{tabular}{|c|c|c|c|c|}
\hline \multirow[t]{2}{*}{ Items, g/100 g } & \multicolumn{2}{|c|}{$1-21$ days } & \multicolumn{2}{|c|}{ 22-42 days } \\
\hline & $\begin{array}{l}\downarrow \text { crude } \\
\text { fiber }\end{array}$ & $\begin{array}{l}\text { Tcrude } \\
\text { fiber }\end{array}$ & $\begin{array}{l}\downarrow \text { crude } \\
\text { fiber }\end{array}$ & $\begin{array}{l}\uparrow \text { crude } \\
\text { fiber }\end{array}$ \\
\hline Corn & 57.54 & 50.65 & 66.66 & 59.75 \\
\hline Soybean hulls & - & 5.00 & - & 5.00 \\
\hline Soybean oil & 1.28 & 3.48 & 2.00 & 4.20 \\
\hline Soybean meal & 37.08 & 36.80 & 27.92 & 27.64 \\
\hline Limestone & 1.08 & 1.02 & 0.94 & 0.88 \\
\hline Dicalcium phosphate & 1.72 & 1.72 & 1.40 & 1.42 \\
\hline Salt & 0.43 & 0.43 & 0.36 & 0.36 \\
\hline Methionine (DL, 98\%) & 0.27 & 0.29 & 0.22 & 0.24 \\
\hline Lysine- $\mathrm{HCl}(\mathrm{L}, 78 \%)$ & 0.15 & 0.14 & 0.19 & 0.18 \\
\hline Threonine (L, 98\%) & 0.03 & 0.04 & 0.03 & 0.042 \\
\hline Choline chloride & 0.12 & 0.12 & 0.04 & 0.05 \\
\hline Vitamin premix ${ }^{1}$ & 0.14 & 0.14 & 0.12 & 0.12 \\
\hline Mineral premix ${ }^{2}$ & 0.12 & 0.12 & 0.08 & 0.08 \\
\hline Inert material (kaolin) ${ }^{3}$ & 0.04 & 0.04 & 0.04 & 0.04 \\
\hline \multicolumn{5}{|l|}{ Calculated composition } \\
\hline $\begin{array}{l}\text { Metabolizable energy } \\
(\mathrm{kcal} / \mathrm{kg})\end{array}$ & 2899 & 2899 & 3050 & 3050 \\
\hline Crude protein, \% & 22.00 & 22.00 & 18.50 & 18.50 \\
\hline Ether extract, \% & 4.154 & 6.209 & 5.030 & 7.750 \\
\hline Crude fiber, \% & 3.065 & 4.557 & 2.790 & 4.280 \\
\hline Dig. Lysine, \% & 1.190 & 1.190 & 1.082 & 1.095 \\
\hline Dig. AAST, \% & 0.857 & 0.857 & 0.800 & 0.800 \\
\hline Dig. Threonine, \% & 0.751 & 0.750 & 0.630 & 0.630 \\
\hline Calcium (\%) & 0.902 & 0.901 & 0.757 & 0.760 \\
\hline Phosphorus (\%) & 0.452 & 0.448 & 0.380 & 0.380 \\
\hline \multicolumn{5}{|c|}{$\begin{array}{l}\text { 'Vitamin premix (content per } \mathrm{kg} \text { of premix): Vit. A 7,000,000.00 IU; Vit. D3 } \\
\text { 2,200,000.00 IU; Vit. E 11,000.00 mg; Vit. K3 1,600.00 mg; Vit. B1 2,000.00 mg; } \\
\text { Vit. B2 5,000.00 mg, Vit. B12 12,000.00 mg; Niacin 35,000.00 mg; Pantothenic Acid } \\
\text { 13,000.00 mg; Folic Acid } 800.00 \text { mg; Antioxidant 100,000.00. }\end{array}$} \\
\hline \multicolumn{5}{|c|}{$\begin{array}{l}\text { Mineral premix (content per } \mathrm{kg} \text { of premix): Iron } 10,000.00 \mathrm{mg} \text {; Copper } 16,000.00 \\
\mathrm{mg} \text {; lodine 2,400.00 mg; Zinc 100,000.00 mg; Manganese 140,000.00 mg; Selenium } \\
400.00 \mathrm{mg} \text {. }\end{array}$} \\
\hline${ }^{3}$ Replaced by $\beta$-mannanas & g/ton) & & & \\
\hline
\end{tabular}

into to 5-mm thick semi-serial sections and stained with hematoxylin-eosin.

For intestinal morphometric analysis, images were captured by light microscopy (Olympus BX 50), using a computerized image analyzer system (ImagePro-Plus - Version 5.2 - Media Cybernetics). In this study, the length and width of 20 villi and depth and width of 20 crypts were measured per slide. These morphometric measures were also utilized for the calculation of the intestinal mucosa absorption surface area, using the formula proposed by Kisielinski et al. (2002): 
Scapini LB, Rorig A, Ferrarini A, Fülber LM, Canavese M, Silva AM, Fernandes JIM

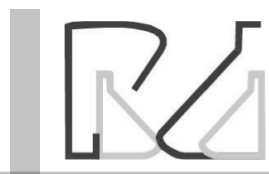

Absorption area:

$((\mathrm{VW} \times \mathrm{VH})+(\mathrm{VW} / 2+\mathrm{CW} / 2) 2-(\mathrm{VW} / 2) 2)$ $((\mathrm{WW} / 2+\mathrm{CW} / 2) 2)$

Where: VWis villus width, $\mathrm{VH}$ is villus height, and CW is crypt width.

\section{Carcass yield}

Carcass yield was determined in two birds per replicate pen (18 birds/treatment). Birds with body weight closest to average body weight of the pen (95\%) were selected, duly identified, and euthanized by electric stunning and bleeding. Carcass yield was calculated as the ratio between hot eviscerated carcass weight and body weight at slaughter. Prime cut yields (whole breast, thigh and drumstick, all including skin and bones), back and wings were calculated relative to eviscerated carcass weight. Abdominal fat around the cloaca, bursa of Fabricius, gizzard, proventriculus, and adjacent abdominal muscles was removed as described by Smith (1993), weighed and calculated relative to eviscerated carcass weight.

\section{Litter Analyses}

After the removal of broilers from the pens at the end of the experiment, litter samples were collected at five points of the pen (four sides and a central
Nutritional Evaluation of Soybean Hulls with or without $\beta$-Mannanase Supplement on Performance, Intestinal Morphometric and Carcass Yield of Broilers Chickens

point), and then homogenized, totaling 36 samples to determine litter $\mathrm{pH}$ and dry matter content.

\section{Statistical Analysis}

Data were checked for the presence of outliers and was tested for normality assumption of study errors (Cramer Von Mises test) and homogeneity of variance (Brown-Forsythe's test).When these assumptions were satisfied, data were submitted to analysis of variance using the GLM procedure of SAS software (SAS Institute, 2002).

\section{RESULTS}

\section{Live performance}

Broiler performance was evaluated for the periods of 1 to 7 days, 1 to 21 days, and 1 to 42 days of age (Table 2).

No effect of treatments nor any interaction among factor ( $p>0.05$ ) were detected on the performance of 1- to 7-d-old broilers.

However, in the period of 1 to 21 days (Table 3), a significant interaction between diet and enzyme supplementation $(p<0.05)$ was observed for feed conversion, and the unfolded results of the interaction are presented in Table 4. The low fiber diet (corn-SBM

Table 2 - Effect of dietary fiber source (soybean hull) and $\beta$-mannanase supplementation on performance of 7-d-old broilers.

\begin{tabular}{lcccc}
\hline Diet & Live weight, $g$ & Gain weight, g & Feed intake, g & Feed conversion ratio \\
\hline Corn-SBM & 182.77 & 135.58 & 166.22 & 1.212 \\
Corn-SBM-SH & 184.71 & 137.42 & 172.11 & 1.258 \\
Enzyme & & & 168.18 & 1.230 \\
0 & 182.88 & 135.70 & 170.16 & 1.241 \\
\hline$\beta$-mannanase & 184.50 & 137.20 & & 0.1022 \\
\hline Analysis of variance & & & & 0.1271 \\
\hline Diet & 0.1560 & 0.1572 & 0.6011 & 0.6787 \\
Enzyme & 0.2579 & 0.2672 & 0.1161 & 0.2147 \\
Diet x Enzyme & 0.4647 & 0.5072 & 6.67 & 6.40 \\
CV, $\%$ & 2.13 & 2.72 & & \\
\hline
\end{tabular}

Table 3 - Effect of dietary fiber source (soybean hull) and $\beta$-mannanase on performance of 21-d-old broilers.

\begin{tabular}{|c|c|c|c|c|}
\hline Diet & Live weight, $\mathrm{g}$ & Gain weight, $g$ & Feed intake, $\mathrm{g}$ & Feed conversion ratio \\
\hline Corn-SBM & 981.02 & 939.18 & 1243.17 & 1.318 \\
\hline Corn-SBM-SH & 997.96 & 953.78 & 1261.95 & 1.316 \\
\hline \multicolumn{5}{|l|}{ Enzyme } \\
\hline 0 & 993.88 & 953.08 & 1257.30 & 1.319 \\
\hline$\beta$-mannanase & 985.09 & 939.88 & 1247.82 & 1.314 \\
\hline \multicolumn{5}{|c|}{ Analysis of variance } \\
\hline Diet & 0.0692 & 0.0857 & 0.2213 & 0.7624 \\
\hline Enzyme & 0.3365 & 0.1184 & 0.5335 & 0.7331 \\
\hline Diet x Enzyme & 0.2352 & 0.1317 & 0.3016 & 0.0130 \\
\hline$C V, \%$ & 2.7314 & 2.61 & 3.61 & 3.22 \\
\hline
\end{tabular}


diet) supplemented with $\beta$-mannanase resulted in better feed conversion.

Table 4 - Unfolded interaction of diet vs. enzyme for the feed conversion ratio of 21-d-old broilers.

\begin{tabular}{lccc}
\hline & 0 & $\beta$-mannanase & $p$-value \\
\hline Corn-SBM diet & 1.3364 & 1.2930 & 0.0560 \\
Corn-SBM-SH diet & 1.3024 & 1.3359 & 0.1180 \\
$p$-value & 0.1084 & 0.0619 & \\
\hline
\end{tabular}

During the grower period (day 22 to day 42 post-hatch) and for the overall period (day 1 to day 42 post-hatch), no interaction between diet and enzyme supplementation was observed for the evaluated performance parameters, and therefore, only the main effects means are presented (Table 5). Neither SH nor $\beta$-mannanase addition had any effect on feed conversion ratio.

Table 5 - Effect of dietary fiber source (soybean hull) and $\beta$-mannanase on performance of 42-d-old broilers.

\begin{tabular}{|c|c|c|c|c|}
\hline Diet & Live weight, $\mathrm{g}$ & Gain weight, g & Feed intake, $\mathrm{g}$ & Feed conversion \\
\hline Corn-SBM & 2781.58 & $2691.37^{b}$ & $4637.98^{b}$ & 1.734 \\
\hline Corn-SBM-SH & 2830.08 & $2761.60^{a}$ & $4774.42^{\mathrm{a}}$ & 1.722 \\
\hline$p$-value & 0.1725 & 0.0256 & 0.0060 & 0.2428 \\
\hline \multicolumn{5}{|l|}{ Enzyme } \\
\hline 0 & 2819.40 & 2746.39 & 4732.26 & 1.728 \\
\hline$\beta$-mannanase & 2792.27 & 2706.59 & 4680.14 & 1.727 \\
\hline \multicolumn{5}{|c|}{ Analysis of variance } \\
\hline Diet & 0.1725 & 0.0256 & 0.0060 & 0.2428 \\
\hline Enzyme & 0.4408 & 0.1938 & 0.2696 & 0.9772 \\
\hline Diet x Enzyme & 0.5571 & 0.2908 & 0.1660 & 0.6290 \\
\hline$C V, \%$ & 3.72 & 3.30 & 2.96 & 1.72 \\
\hline
\end{tabular}

a-b Means with different lowercase superscripts in the same column significantly differ $(p<0.05)$.

At 42 days, the weight gain $(p<0.05)$ and feed intake $(p<0.05)$ of the birds fed diets containing SH was $2.6 \%$ and $2.9 \%$ higher than those of birds fed corn-SBM diets, respectively, independently of enzyme supplementation.

\section{Organ weight and intestinal analyses}

At 21 days, higher relative liver weight $(p<0.05)$ was determined in broilers fed the corn-SBM-SH diet $(p<0.05)$ and those fed enzyme-supplemented diets $(p<0.05)$ (Table 6).

Table 6 - Effect of dietary fiber source (soybean hull) and $\beta$-mannanase on organ relative weight of 21- and 42-d-old broilers.

\begin{tabular}{|c|c|c|c|c|}
\hline \multirow{2}{*}{ Diet } & Bursa, \% & Intestine, \% & Pancreas, \% & Liver, \% \\
\hline & \multicolumn{4}{|c|}{21 days } \\
\hline Corn-SBM & 0.25 & 7.65 & 0.32 & $2.54^{b}$ \\
\hline Corn-SBM-SH & 0.25 & 7.98 & 0.31 & $2.69^{a}$ \\
\hline \multicolumn{5}{|l|}{ Enzyme } \\
\hline 0 & 0.25 & 7.72 & 0.31 & $2.55^{b}$ \\
\hline$\beta$-mannanase & 0.26 & 7.90 & 0.31 & $2.67^{\mathrm{a}}$ \\
\hline \multicolumn{5}{|c|}{ Analysis of variance } \\
\hline Diet & 0.7025 & 0.1528 & 0.5003 & 0.0122 \\
\hline Enzyme & 0.4994 & 0.4189 & 0.7868 & 0.0345 \\
\hline Diet x Enzyme & 0.6074 & 0.1649 & 0.8924 & 0.8142 \\
\hline \multirow[t]{2}{*}{$C V, \%$} & 15.36 & 8.22 & 15.66 & 6.54 \\
\hline & \multicolumn{4}{|c|}{42 days } \\
\hline \multicolumn{5}{|l|}{ Diet } \\
\hline Corn-SBM & 0.11 & 4.58 & 0.18 & 2.02 \\
\hline Corn-SBM-SH & 0.12 & 4.73 & 0.18 & 2.06 \\
\hline \multicolumn{5}{|l|}{ Enzyme } \\
\hline 0 & 0.13 & 4.72 & 0.17 & 2.09 \\
\hline$\beta$-mannanase & 0.11 & 4.57 & 0.18 & 1.99 \\
\hline \multicolumn{5}{|c|}{ Analysis of variance } \\
\hline Diet & 0.4069 & 0.4401 & 0.6930 & 0.5415 \\
\hline Enzyme & 0.2775 & 0.4565 & 0.5261 & 0.1925 \\
\hline Diet x Enzyme & 0.8164 & 0.9644 & 0.4403 & 0.0034 \\
\hline$C V, \%$ & 48.07 & 11.95 & 15.09 & 11.26 \\
\hline
\end{tabular}

a-b Means with different lowercase superscripts in the same column significantly differ $(p<0.05)$. 
At 42 days, there was an interaction $(p<0.05)$ between diet and enzyme for relative liver weight $(p<0.05)$. When the interaction was unfolded (Table 7), it was observed that the diet with $\mathrm{SH}$ and supplemented with $\beta$-mannanase promoted higher relative liver weight $(p<0.05)$.

Table 7 - Unfolded interaction of diet vs enzyme for relative liver weight of broilers at 42 days of age.

\begin{tabular}{lccc}
\hline & 0 & $\beta$-mannanase & $p$-value \\
\hline Corn-SBM diet & 2.09 & $1.95^{\mathrm{b}}$ & 0.2408 \\
Corn-SBM-SH diet & $1.89^{\mathrm{B}}$ & $2.24^{\mathrm{aA}}$ & 0.0032 \\
$p$-value & 0.0851 & 0.0183 & \\
\hline
\end{tabular}

A-BMeans with different upper case superscripts in the same row significantly differ $(p<0.05)$.

${ }^{a-b}$ Means with different lowercase superscripts in the same column significantly differ $(p<0.05)$.
At 21 days of age, no significant differences ( $p>0.05)$ in the morphometry of the small intestine were observed among treatments (Table 8). However, at 42 days of age, the birds supplemented with $\beta$-mannanase presented shorter jejunal villi $(p<0.05)$ and therefore, smaller absorption area $(p<0.05)$, independently of fiber source.

\section{Carcass yield}

The inclusion of $5 \% \mathrm{SH}$ in the diet and enzyme supplementation did not affect protein deposition ( $p>0.05)$ (Table 9). There was an interaction between factors $(p<0.05)$ for abdominal fat content $(p<0.05)$. The unfolding of the interaction shows that the diet with SH $(p<0.05)$ and no inclusion of $\beta$-mannanase resulted in a lower carcass fat percentage (Table 10).

Table 8 - Effect of dietary fiber source (soybean hull) and $\beta$-mannanase on intestinal mucosa morphology of broilers from 21 and 42 days old.

\begin{tabular}{|c|c|c|c|c|c|c|c|c|c|c|c|c|}
\hline \multirow{3}{*}{ Diet } & \multicolumn{2}{|c|}{ Villus, $\mu \mathrm{m}$} & \multicolumn{2}{|c|}{ Crypts, $\mu \mathrm{m}$} & \multirow{2}{*}{$\begin{array}{l}\text { Ratio } \\
V: C\end{array}$} & \multirow{2}{*}{$\begin{array}{l}\text { Absorption } \\
\text { area, } \mu m^{2}\end{array}$} & \multicolumn{2}{|c|}{ Villus, $\mu \mathrm{m}$} & \multicolumn{2}{|c|}{ Crypts, $\mu \mathrm{m}$} & \multirow[t]{2}{*}{ C:VRatio } & \multirow{2}{*}{$\begin{array}{l}\text { Absorption } \\
\text { area, } \mu m^{2}\end{array}$} \\
\hline & Length & width & depth & length & & & length & width & depth & length & & \\
\hline & \multicolumn{6}{|c|}{ Duodenum - 21 days } & \multicolumn{6}{|c|}{ Duodenum -42 days } \\
\hline Corn-SBM & 1740.94 & 138.12 & 181.31 & 44.90 & 9.39 & 28.29 & 1779.49 & 152.64 & 182.15 & 43.11 & 10.12 & 29.59 \\
\hline Corn-SBM-SH & 1714.30 & 139.63 & 181.76 & 44.84 & 9.50 & 28.66 & 1754.53 & 151.85 & 178.53 & 42.89 & 10.15 & 29.32 \\
\hline \multicolumn{13}{|l|}{ Enzyme } \\
\hline 0 & 1724.90 & 140.06 & 181.72 & 44.93 & 9.42 & 28.27 & 1784.81 & 151.86 & 195.61 & 43.73 & 9.28 & 29.70 \\
\hline$\beta$-mannanase & 1728.78 & 137.70 & 181.35 & 44.80 & 9.47 & 28.68 & 1812.51 & 129.19 & 175.38 & 40.39 & 10.71 & 32.79 \\
\hline \multicolumn{13}{|c|}{ Analysis of variance } \\
\hline Diet & 0.5584 & 0.8969 & 0.9046 & 0.8534 & 0.8097 & 0.5963 & 0.6171 & 0.1511 & 0.5013 & 0.2488 & 0.7200 & 0.2194 \\
\hline Enzyme & 0.9466 & 0.8397 & 0.9217 & 0.6797 & 0.9130 & 0.5663 & 0.7598 & 0.2158 & 0.0672 & 0.1048 & 0.0706 & 0.3183 \\
\hline Diet x Enzyme & 0.7542 & 0.9047 & 0.8074 & 0.4241 & 0.8353 & 0.9574 & 0.5578 & 0.5510 & 0.5368 & 0.0188 & 0.4862 & 0.1318 \\
\hline$C V, \%$ & 7.58 & 25.03 & 6.15 & 2.19 & 14.90 & 7.37 & 13.05 & 36.14 & 16.39 & 11.73 & 21.79 & 26.11 \\
\hline & \multicolumn{6}{|c|}{ Jejunum - 21 days } & \multicolumn{6}{|c|}{ Jejunum - 42 days } \\
\hline \multicolumn{13}{|l|}{ Diet } \\
\hline Corn-SBM & 882.59 & 200.64 & 135.13 & 53.21 & 6.55 & 11.35 & 900.66 & 139.83 & 131.15 & 43.52 & 7.11 & 15.39 \\
\hline Corn-SBM-SH & 885.65 & 197.96 & 134.44 & 52.96 & 6.57 & 11.48 & 913.31 & 146.53 & 130.52 & 45.01 & 6.94 & 15.36 \\
\hline \multicolumn{13}{|l|}{ Enzyme } \\
\hline 0 & 884.79 & 198.26 & 134.61 & 53.16 & 6.59 & 11.48 & $1001.61^{a}$ & 140.33 & 138.00 & 44.05 & 7.32 & $17.32^{\mathrm{a}}$ \\
\hline$\beta$-mannanase & 883.30 & 200.34 & 134.97 & 53.02 & 6.53 & 11.35 & $792.17^{b}$ & 145.93 & 122.82 & 44.42 & 6.72 & $13.18^{b}$ \\
\hline \multicolumn{13}{|c|}{ Analysis of variance } \\
\hline Diet & 0.7891 & 0.8022 & 0.9021 & 0.8443 & 0.9626 & 0.8278 & 0.8913 & 0.5530 & 0.9512 & 0.4117 & 0.6433 & 0.6168 \\
\hline Enzyme & 0.9106 & 0.8455 & 0.9489 & 0.9164 & 0.8561 & 0.8353 & 0.0072 & 0.6127 & 0.2721 & 0.7722 & 0.2348 & 0.0023 \\
\hline Diet x Enzyme & 0.8249 & 0.8024 & 0.7572 & 0.8288 & 0.8512 & 0.8685 & 0.8325 & 0.6857 & 0.3667 & 0.4343 & 0.2675 & 0.8269 \\
\hline$C V, \%$ & 3.60 & 15.94 & 12.41 & 7.21 & 16.11 & 15.04 & 22.88 & 22.44 & 28.66 & 12.76 & 22.83 & 22.09 \\
\hline & \multicolumn{6}{|c|}{ Ileum - 21 days } & \multicolumn{6}{|c|}{ Ileum - 42 days } \\
\hline \multicolumn{13}{|l|}{ Diet } \\
\hline Corn-SBM & 550.86 & 159.18 & 145.72 & 44.35 & 3.78 & 8.86 & 493.17 & 147.95 & 126.80 & 42.37 & 3.93 & 8.01 \\
\hline Corn-SBM-SH & 551.85 & 159.62 & 144.49 & 44.44 & 3.82 & 8.85 & 483.53 & 145.44 & 130.42 & 42.42 & 3.83 & 8.50 \\
\hline \multicolumn{13}{|l|}{ Enzyme } \\
\hline 0 & 550.57 & 159.18 & 145.55 & 44.38 & 3.78 & 8.85 & 530.71 & 148.76 & 130.02 & 40.89 & 4.16 & 8.70 \\
\hline$\beta$-mannanase & 552.14 & 159.61 & 144.66 & 44.40 & 3.82 & 8.86 & 430.81 & 144.12 & 125.88 & 44.39 & 3.46 & 7.65 \\
\hline \multicolumn{13}{|c|}{ Analysis of variance } \\
\hline Diet & 0.9457 & 0.8538 & 0.3028 & 0.7765 & 0.7206 & 0.9626 & 0.8510 & 0.7631 & 0.7527 & 0.5903 & 0.9015 & 0.7844 \\
\hline Enzyme & 0.9136 & 0.8585 & 0.4497 & 0.9616 & 0.7284 & 0.9738 & 0.0710 & 0.6003 & 0.6473 & 0.0270 & 0.1754 & 0.3672 \\
\hline Diet x Enzyme & 0.9598 & 0.8147 & 0.5079 & 0.7995 & 0.9050 & 0.9215 & 0.1949 & 0.8379 & 0.8778 & 0.1217 & 0.1354 & 0.1022 \\
\hline$C V, \%$ & 7.79 & 4.47 & 2.42 & 2.24 & 8.38 & 7.96 & 27.45 & 16.47 & 17.04 & 10.78 & 28.01 & 21.98 \\
\hline
\end{tabular}


Table 9 - Effect of dietary fiber source (soybean hull) and $\beta$-mannanase on carcass and cuts yield of broilers from 42 days old.

\begin{tabular}{lcccc}
\hline Diet & Carcass, $\%$ & Legs, $\%$ & Breast, \% & Abdominal fat, $\%$ \\
\hline Corn-SBM & 75.58 & 27.49 & 33.03 & 2.06 \\
Corn-SBM-SH & 75.03 & 27.66 & 32.95 & 2.04 \\
Enzyme & & & & \\
0 & 75.25 & 27.46 & 32.89 & 2.07 \\
B-mannanase & 75.36 & 27.70 & 33.10 & 2.02 \\
\hline Analysis of variance & & & & 0.8646 \\
\hline Diet & 0.1155 & 0.6809 & 0.7240 & 0.6887 \\
Enzyme & 0.6987 & 0.5765 & 0.2447 & 0.0132 \\
Diet x Enzyme & 0.6193 & 0.8078 & 5.93 & 17.51 \\
CV, $\%$ & 1.32 & 4.28 & & \\
\hline
\end{tabular}

Table 10 - Unfolded interaction of diet vs enzyme for abdominal fat (\%) of broilers at 42 days of age.

\begin{tabular}{lccc}
\hline & 0 & $\beta$-mannanase & $p$-value \\
\hline Corn-SBM diet & 1.92 & 2.19 & 0.1355 \\
Corn-SBM-SH diet & $2.22^{\mathrm{A}}$ & $1.86^{\mathrm{B}}$ & 0.0481 \\
$p$-value & 0.1006 & 0.0662 & \\
\hline
\end{tabular}

${ }^{A-B}$ Means with different superscripts the same row significantly differ $(p<0.05)$.

\section{Litter Analyses}

As shown in Table 11, there was no effect of the treatments $(p>0.05)$ on the evaluated poultry litter parameters. Litter dry matter content was not higher when birds were fed the diets supplemented with enzymes, as expected.

Table 11 - Effect of dietary fiber source (soybean hull) and $\beta$-mannanase on dry matter and $\mathrm{pH}$ of poultry litter.

\begin{tabular}{lcc}
\hline Diet & dry matter, \% & $\mathrm{pH}$ \\
\hline Corn-SBM & 61.45 & 8.15 \\
Corn-SBM-SH & 61.66 & 8.23 \\
Enzyme & & \\
0 & 62.06 & 8.19 \\
$\beta$-mannanase & 61.05 & 8.19 \\
\hline Analysis of variance & & \\
\hline Diet & 0.8871 & 0.5380 \\
Enzyme & 0.4994 & 0.9839 \\
Diet x Enzyme & 0.4625 & 0.7684 \\
CV, \% & 7.25 & 5.00 \\
\hline
\end{tabular}

\section{DISCUSSION}

The best feed conversion ratio obtained at 21 days of age with the low-fiber diet supplemented with $\beta$-mannanase corroborates other findings on the positive effects of the addition of enzymes on dietary fiber. Jackson et al. (2004) obtained a positive effect of the addition of $\beta$-mannanase in broiler starter and grower pelleted diets on weight gain. Daskiran et al. (2004) added different levels of $\beta$-mannan and $\beta$-mannanases in the diets of broiler chickens up to 14 days of age, and concluded that enzyme supplementation improves feed utilization and increases the weight gain at high levels of $\beta$-mannans, although this response was observed late during the evaluated period, as well better feed conversion ratio.

The $\beta$-mannan content of SBM diets evidently depends upon the level of SBM inclusion. For illustrative purposes, a broiler starter diet containing 35\% dehulled SBM may contain $0.44 \% \beta$-mannan. If this diet was formulated with soybean hull, the $\beta$-mannan level would be considerably higher. Therefore, poultry nutritionists need to take into account the significant $\beta$-mannan content of SBM and consider the use of exogenous dietary enzymes to improve bird performance (Hsiao et al., 2006).

Enzymes are considered energy-releasing when they reduce fiber viscosity and improve performance via passage rate or increase nutrient digestibility by "opening up" feed components that the animal is unable to access on its own. In particular, $\beta$-mannanase is an energy-sparing enzyme for growth and performance.

The action of NSP on the GIT is primarily physical, as the cell wall acts as a barrier for nutrient release or increases digesta viscosity, limiting nutrient absorption (BackKnudsen et al., 2001). On the other hand, Mateos et al. (2012) showed that moderate dietary fiber levels improve the gizzard function, increasing gastroduodenal reflux, thereby facilitating the contact between nutrients and digestive enzymes. Moreover, this difference in GIT functionality may influence microbial growth rate in different digestive organs. 
Scapini LB, Rorig A, Ferrarini A, Fülber LM, Canavese M, Silva AM, Fernandes JIM
Nutritional Evaluation of Soybean Hulls with or without $\beta$-Mannanase Supplement on Performance, Intestinal Morphometric and Carcass Yield of Broilers Chickens
Certain oligosaccharides are considered prebiotic compounds because they are not hydrolyzed in the upper GIT and are able to favorably alter the colonic microflora, which confer beneficial effects to the host by digesting and fermenting these carbohydrates (Pan \& Yu, 2014).

The level of crude fiber on commercial diets for broiler chickens is usually below 3\%. In the present study, the highest level of crude fiber used was around $4.5 \%(5 \%$ of $\mathrm{SH})$, which possibly did not pose a challenge to the birds. According to published studies, diets containing moderate levels of digestible fiber favor organ development and increase the secretion of hydrochloric acid, bile salts and enzymes (Back Knudesen, 2001, Sklan et al. 2003).

Our results agree with the findings of Azarfar (2013), who supplemented diets based on corn and SBM meal with $\beta$-mannanase $(0.5$ and $1.0 \mathrm{~g} / \mathrm{kg})$ and did not observe any improvement in weight gain, feed intake and feed conversion throughout the experimental period (days 1-42). On the other hand, Hajati (2010), evaluating the supplementation of anenzyme blend to breakdown dietary NSPs, obtained higher weight gain in 1- to 44-d-old broilers fed the non-supplemented diet, but lower feed intake and feed conversion ratio in those supplemented with the enzyme blend.

The mode of action of $\beta$-mannanase is complex and is related to the reduction of $\beta$-mannans in the digesta. It reduces digesta viscosity, improving nutrient absorption, and consequently, animal performance. Secondly, it improves energy metabolism (Jackson, 2010) because it stimulates insulin secretion and blocks the negative effect of $\beta$-mannans on glucose absorption (Jackson et al., 2004). Finally, $\beta$-mannanase reduce the stimulation of the innate immune system caused by $\beta$-mannans, as shown by the observed reduction of macrophages, monocytes, and cytokine production (Jackson et al., 2004; Hsiao et al., 2006). The molecular pattern of mannans is similar to that of some pathogens, triggering a "feed-induced immune response" in poultry (Stahl \& Ezekowitz, 1998). This unnecessary innate immune system stimulation consumes energy and other valuable nutrients, leaving less energy available for growth and performance.

According to Hsiao et al. (2006), it is presumed that different soybean cultivars may have different $\beta$-mannan contents, and consequently, in feeds. As $\beta$-mannans are mainly found in the soybean hulls, their levels might have been slightly higher in the cornSBM-SH diet than in the corn-SBM diet. Considering that $\beta$-mannanase product used in this study was developed for corn-SBM diets, probably enzyme levels higher than that included in the present study $(400$ $\mathrm{mg} / \mathrm{kg}$ ) may be necessary for diets containing $\mathrm{SH}$. Thus, simple sugars released from this portion was not enough to account for the improved development and growth of the GIT mucosa.

Independently of enzyme supplementation, broilers fed the diet with SH showed higher liver weight both at 21 and 42 days of age, which indicates that liver activity is associated with dietary fiber level. Soluble fiber reduces intestinal transit rate by increasing digesta viscosity, which acts as a physical barrier against the action of enzymes and bile salts, whereas insoluble fibers increase intestinal transit rate, both causing lower nutrient digestibility and absorption. Consequently, a higher amount of undigested feed reaches the large intestine and is available for fermentation by microbes, which produce short-chain fatty acids that are metabolized in the liver, increasing its size. However, these short chair fatty acids may serve as an energy source for its the mucosa of the large intestine, particularly of the cecum, and do not reach the liver. Therefore, further research is needed to better elucidate this issue.

In both human and animal nutrition, several fiber components are currently being scrutinized for their beneficial effects on gut health and potential to modify the gut microflora. The emphasis on their negative or positive attributes is related to their dietary inclusion level. At low inclusion levels, NSPs may beneficially modify the gut microflora, especially in situations where antibiotic growth promoters are not used (Lesson, 2012).

Azarfar (2013) evaluated $\beta$-mannanase supplementation in broiler diets, and observed the liver weight of birds fed $0.05 \mathrm{~g} / \mathrm{kg}$ of diet was higher than those fed with $1.0 \mathrm{~g} / \mathrm{kg}$, but not statistically different from the broilers fed non-supplemented diets. On the other hand, Hajati (2010) did not find any significant effects of supplementation of an enzyme blend on organ weights of 44-d-old broilers.

Broiler carcass yield was not influenced by the studied treatments. The only significant result obtained was lower carcass fat percentage in broilers fed the diet with moderate fiber levels and no enzyme inclusion; however, this indirect effect of DF still needs to be elucidated. In the study of Hajati (2010), the supplementation of an enzyme blend (xylanase and $\beta$-glucanase) influenced only the leg yield of 44 -d-old broilers at 44 days of age, and the author argues that the responses to enzyme supplementation depend on 
Scapini LB, Rorig A, Ferrarini A, Fülber LM, Canavese M, Silva AM, Fernandes JIM

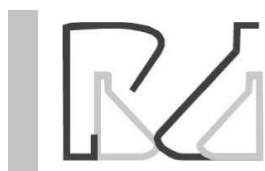

bird age, because type of microbiota and physiology are related to age.

According to Kaczmarek et al. (2014), the mode of action of enzymes which degrade NSPs is based on the elimination of the physical barrier between the cell wall and the endosperm and encapsulated nutrients. Therefore, the partial hydrolysis of insoluble NSPs may reduce the cage effect and make the nutrients inside the plant cells more accessible to digestive enzymes. Since starch is the main constituent of endosperm cells in cereals, the improvement of precaecal starch digestibility suggests that the applied enzyme contributed to reduce the cage effect. Therefore, dietary enzyme supplementation is expected to promote better nutrient utilization, especially after the first week of life, and consequently, better live performance.

There was no effect of the enzyme evaluated in this study on litter parameters. One of the purposes of dietary $\beta$-mannanase inclusion is to reduce digesta viscosity of NSP-rich diets, as highly viscous diets increase water excretion, which may cause wet litter.

There is a renewed interest in fiber nutrition of all classes of poultry, in terms of both gut health and effect on microflora. It is also important to consider that the gut microbiome is now recognized as an essential component of the intestinal ecosystem and is referred to as "the forgotten organ," which contributes to the welfare of the host in a wide range of aspects, especially nutrition and disease resistance. It is possible to gain a comprehensive knowledge of not only the compositional, but also the metabolic characteristics of the gut microbiome and the interactions among gut microbiome, diet, and host (Pan \& Yu, 2014).

Manipulations of the gut microbiome through dietary and management interventions have been used by poultry producers to enhance bird growth and reduce the incidence of diseases. Further studies on how fiber sources and levels impact gut health, performance, and economics can potentially provide the knowledge base needed to develop alternative strategies in modern poultry production.

\section{CONCLUSIONS}

Broilers fed the corn-SBM diet supplemented with $\beta$-mannanase had better feed conversion at 21 days of age.

The dietary inclusion of $5 \% \mathrm{SH}$ in the corn-SBM diet resulted in higher feed intake, weight gain, relative liver weight, and lower fat abdominal percentage, but did not alter the intestinal morphometry.
Nutritional Evaluation of Soybean Hulls with or without $\beta$-Mannanase Supplement on Performance, Intestinal Morphometric and Carcass Yield of Broilers Chickens

The obtained data suggest that broilers may have a nominal requirement for insoluble fiber; however, the dietary fiber source and inclusion rate may be important factors to satisfy dietary fiber requirements of broilers.

\section{REFERENCES}

Azarfar A. Effect of hemicell enzyme on the performance, growth parameter, some blood factors and ileal digestibility of broiler chickens fed corn/soybean-based diets. Journal of Cell and Animal Biology 2013;7(7):85-91.

Back Knudesen KE. The nutricional significance of "dietary fibre" analysis. Animal Feed Science and Technology 2001;90(9):3-20.

Back Knudesen KE. Fiber and nonstarch polysaccharide content and variation in common crops used in broiler diets. Poultry Science 2014;93(9):2380-2393.

Choct M, Kocher A, Waters DLE, Pettersson D, Ross, G. A comparasion of three xylanases on the nutritive value of two wheats for broiler chickens. British Journal of Nutrition 2004;92(1):53-61.

Choct M, Annison G. Anti-nutritive effect of wheat pentosans in broiler chickens: roles of viscosity and gut microflora. British Poultry Science 1992;33(4):821-834.

Daskiran M, Teeter RG, Fodge D, Hsiao HY. An evaluation of endo- $\beta-D-$ mannanae (Hemicell) effects on broiler performance and energy use in diets varying in $\beta$-mannan content. Poultry Science 2004;83(1):662668.

Dierick NA. Biotechnology aids to improve feed and feed digestion: Enzyme and fermentation. Archives of Animal Nutrition 1989;39(3):241-261.

González-Alvarado JM, Jiménez-Moreno E, Lázaro R, Mateos GG. Effect of type of cereal, heat processing of the cereal, and inclusion of fiber in diet on productive performance and digestive traits of broilers. Poultry Science 2007;86(8):1705-1715.

Hajati $H$. Effects of enzyme suplementation on performance, carcass chacarteristics, carcass composition and some blood parameters of broiler chicken. American Journal of Animal and Veterinary Sciences 2010;5(3):221-227.

Hsiao HY, Anderson DM, Dale NM. Levels of $\beta$-mannan in soybean meal. Poultry Science 2006;85(8):1430-1432

Hughes BO, Duncan IJ. The influence of line and environmental factors upon feather pecking and cannibalism in fowls. British Poultry Science 1972;13(6):525-547.

Jackson ME, Geronian K, Knox A, Mcnab J, Mccartney E. A dose-response study with the feed enzyme $\beta$-mannanase in broilers provided with corn-soybean meal based diets in the absence of antibiotic growth promoter. Poultry Science 2004;83(12):1992-1996.

Jackson ME, Fodge DW, Hsiao HY. Effects of $\beta$-mannanase in cornsoybean meal diets on laying hen performance. Poultry Science 1999;78(12):1737-1741.

Jackson ME.,. Mannanase, alpha-galactosidase and pectinase. In: Bedford MR, Partridge GG, editors. Enzymes in farm animal nutrition. London: CABI Publishing; 2010. p.54-84.

Jiménez-Moreno E, De Coca-Sinova A, González-Alvarado JM, Mateos GG. Inclusion of insoluble fiber sources in mash or pellet diets for Young broilers. Effect on growth performance and water intake. Poultry Science 2016;95(1):41-52. 
Scapini LB, Rorig A, Ferrarini A, Fülber LM, Canavese M, Silva AM, Fernandes JIM

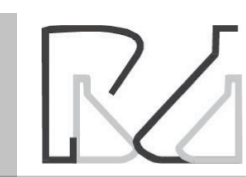

Nutritional Evaluation of Soybean Hulls with or

without $\beta$-Mannanase Supplement on Performance, Intestinal Morphometric and Carcass Yield of Broilers Chickens
Kaczmarek SA, Rogiewicz A, Mogielnicka M, Rutkowski A, Jones RO, Slominski BA. The effect of protease, amylase, and nonstarch polysaccharide-degrading enzyme supplementation on nutriente utilization and growth performance of broiler chickens fed cornsoybean meal-based diets. Poultry Science 2014;93(7):1745-1753.

Kamada K, Chen GY, Inohara N, Núñez G. Control of pathogens and pathobionts by the gut microbiota.Nature Immunology 2013;14(7):685690.

Kong C, Lee J.H, Adeola O. Supplementation of $\beta$-mannanase to starter and grower diets for broilers. Canadian Journal of Animal Science 2011;91(3):389-397

Lee JT, Baile CA, Cartwright AL. $\beta$-mannanase ameliorates viscosityassociated depression of growth in broiler chickens fed guar germ and hull fractions. Poultry Science 2003;82(12):1925-1931.

Lesson S. Future considerations in poultry nutrition. Poultry Science 2012;91(2):1281-1285.

Lo GS. Nutricional and physical properties of dietary fiber from soybeans. Cereal Foods World 1989;34:530-534.

Mateos GG, Jiménez-Moreno E, Serrano MP, Lázaro RP. Poultry response to high levels of dietary fiber soucers varying in physical and chemical characteristics. The Journal of Applied Poultry Research 2012:21(1):156174

McCleary BV. Beta-D-mannanase. Methods Enzymology 1988;160:596615.

Nicholson JK, Holmes E, Kinross J, Burcelin R, Gibson G, Jia W, et al. Hostgut microbiota metabolic interactions. Science 2012;336(6086):12621267

Pan D, Yu Z. Intestinal microbiome of poultry and its interaction with host and diet. Gut Microbes 2014;5(1):108-119.

Rogel AM, Balnave D, Bryden WL, Annison EF. The digestion of wheat starch in broiler chickens. Australian Journal of Agricultural Research 1987;38(3):639-649.

Sklan D, Smirnov A, Plavnik I. The effect of dietary fibre on the small intestines and apparent digestion in the turkey. British Poultry Science 2003;44(5):735-740.

Stahl P, Ezekowitz R. The mannose receptor is a pattern recognition receptor involved in host defense. Current Opinion in Immunology 1998; 10(1):50-55 